\title{
Risk Analysis Income of Fish Business at Ranau Lake of South Sumatera Indonesia
}

\author{
Fifian Permatasari ${ }^{1}$,and Munajat ${ }^{2 *}$ \\ ${ }^{1}$ Agribusiness Study Program, Faculty of Agriculture, University of Baturaja, Indonesia \\ ${ }^{2}$ Agribusiness Study Program, Faculty of Agriculture, University of Baturaja, Indonesia
}

\begin{abstract}
This study aimed to analyse the risk income of fish business in Ranau Lake of South Sumatera Indonesia. The location is determined by purposive on the banks of Ranau Lake, South OKU, South Sumatera Province, Indonesia. The method of this research is case study method, and simple random sampling as the sample method, with take 62 samples of 81 total population. The result showed that the income from this business is Rp 148.459 .460 a year. Risk analysis showed that this business will not face risk significantly, which is indicated by the coefficient of variation of 0.0892004791 with a lower limit value of the income is $\operatorname{Rp} 121.974 .150 .081$.
\end{abstract}

\section{Introduction}

The lake is a very important natural resource for human life. Based on the type of goods and ownership, the lake is a common good that is shared by the community. Because of its general nature then everyone is open to use it freely according to his needs. This situation will lead to lake resources will tend to be utilized in accordance with the needs of the surrounding community, regardless of its sustainability. In turn there will be an inevitable condition that is a conflict of interest, both in utilization and authority in the management, so that it can threaten the sustainability of these resources [4].

Indonesia has more than 700 lakes with a total area of more than $5,000 \mathrm{~km}$ or about $0.25 \%$ of the land area of Indonesia [2], Lake Ranau is one of the lakes in the Province of South Sumatra, Indonesia precisely in South OKU Regency which has great potential for the development of fisheries business, one of them in the form of floating net cages (KJA). Fish business in KJA is the most productive method of aquaculture today. This is due to several factors of excess in the application of KJA techniques such as high stocking of seeds, availability of water quantity, not requires soil treatment, control of predatory disturbances is relatively easy, harvesting is easier, and can be moved to another location [6].

Fish business using floating net cages pattern (KJA's pattern) in South Sumatra is centered in South Ogan Komering Ulu (OKU) Regency. South OKU Regency has several lakes including Ranau Lake which is used by the community for freshwater fish business KJA Pattern and very strategic for the development of fish business Mujair KJA pattern because it is located along Lake Ranau. Statistical data of Department of Fisheries and Marine of South Sumatra. 2016, indicates the production of freshwater fish of South Ogan Komering Ulu Regency is as follows in Table 1.

\footnotetext{
* Corresponding author: fifianpermatasari@unbara.ac.id, munajat@unbara.ac.id.
} 
Table 1. Freshwater fish production in Ranau Lake, 2016

\begin{tabular}{|c|c|c|c|}
\hline No & District & $\begin{array}{c}\text { Production } \\
\text { (Ton) }\end{array}$ & $\begin{array}{c}\text { Values } \\
\text { (Rp.000) }\end{array}$ \\
\hline 1 & Mekakau Ilir & 14.776 & 14.776 \\
2 & Banding Agung & 79.104 & 79.104 \\
3 & BPR.RanauTengah & 27.520 & 27.520 \\
4 & Warkuk Ranau Selatan & 93.580 & 93.580 \\
5 & Buay Pemaca & 22.800 & 22.800 \\
6 & Simpang & 8.390 & 8.390 \\
7 & Buana Pemaca & 14.500 & 14.500 \\
8 & Muaradua & 59.112 & 59.112 \\
9 & Buay Rawan & 20.310 & 20.310 \\
10 & Buay Sandang Aji & 27.430 & 27.430 \\
11 & Tiga Dihaji & 23.000 & 23.000 \\
12 & Buay Runjung & 23.380 & 23.380 \\
13 & Runjung Agung & 21.640 & 21.640 \\
14 & Kisam Tinggi & 18.280 & 18.280 \\
15 & Muaradua Kisam & 13.230 & 13.230 \\
16 & Kisam Ilir & 28.260 & 28.260 \\
17 & Pulau Beringin & 32.366 & 32.366 \\
18 & Sindang Danau & 27.800 & 27.800 \\
19 & Sungai Are & 10.440 & 10.440 \\
\hline & Amount & 565.918 & 565.918 \\
& & & \\
\hline
\end{tabular}

Table 1 shows that the freshwater fish production in South OKU Regency, South Sumatera Province reaches 565.918 ton a year. Fish business with KJA pattern itself is located along Lake Ranau precisely in Warkuk Ranau South District. This business has been in existence for 10 years as a result of the low price of coffee received by farmers at that time. The fish business using floating net cage pattern (KJA) along Lake Ranau requires a large business capital, but the benefits that will be in can also quite high. Harvest fish can be done 4 times in 1 year. However, many people who remain interested in the business of mujair fish with the pattern of floating net cages. On the other hand, fish business along the Ranau Lake has many risks, including production risk and the income risk itself. Based on this background, it is interesting to learn more about the risk analysis income of fish business in floating net cages at South OKU Regency, South Sumatera Indonesia.

\section{Materials and Methods}

This research has carried out in South OKU Regency, South Sumatera Indonesia as the center of fish business using floating net cages along the Ranau Lake. The research method use case study method and the samples were taken randomly, with simple random sampling method. The total population of fish business with floating net cages are 81 and taken 62 as the samples with the same size of KJA and same fish inside their KJA i.e Mujair Fish. The amount of income of this business can be calculated using the this following formula :

$\mathrm{Pd}=\mathrm{Pn}-\mathrm{BT}$
$\mathrm{Pn}=\mathrm{Y}$ x Hy
$\mathrm{BT}=\mathrm{BTp}+\mathrm{BV}$

Where :

$\mathrm{Pd}=$ The income of fish business in floating net cage $(\mathrm{Rp} / \mathrm{yr})$

$\mathrm{Pn}=$ Revenue $(\mathrm{Rp} / \mathrm{yr})$

$\mathrm{Y}=$ Number of Fish Production $(\mathrm{Rp} / \mathrm{yr})$

$\mathrm{Hy}=$ Selling Price of Fish $(\mathrm{Rp} / \mathrm{Kg} / \mathrm{yr})$

$\mathrm{BT}=$ Total Cost of Fish Business (Rp/yr)

$\mathrm{BTp}=$ Fixed Cost of Fish Business (Rp/yr)

$\mathrm{BV}=$ Variable Cost of Fish Business $(\mathrm{Rp} / \mathrm{yr})$

To analyse the risk of fish business using floating net cage pattern, can be calculated as follows:

$\begin{aligned} E & =\frac{\sum_{i=1}^{n} E i}{n} \\ C V & =\frac{V}{E} \\ V^{2} & =\frac{\sum_{i=1}^{n}(E i-E)^{2}}{(n-1)}\end{aligned}$ 
$\mathrm{V}=\sqrt{\mathrm{V}^{2}}$

$\mathrm{L}=\mathrm{E}-2 \mathrm{~V}$

Information :

$\mathrm{E}=$ Average value of revenue (Rp)

$\mathrm{Ei}=$ Value of the $\mathrm{i}$-th earnings $(\mathrm{Rp})$

$\mathrm{n}=$ Number of Samples

$\mathrm{CV}=$ Coefficient of Variation

$\mathrm{V}=$ Standard deviation

$\mathrm{L}=$ Lower limit of revenue $(\mathrm{Rp})$

Rule of decision (Kadarsan, 1995):

1. If $\mathrm{CV}>0.5$ then the value of $\mathrm{L}<0=$ fish business opportunity to lose

2. If $\mathrm{CV} \leq 0.5$ then the value of $\mathrm{L} \geq 0=$ The business of fish avoid the loss

\section{Results and Discussions}

The cost of production is all costs that must be incurred in the business of fish consisting of fixed costs and variable costs. The variable cost of fish business is the cost of seeds, feed, medicines and labor. While fixed costs are included in fixed costs include bamboo, waring, wooden beams, ropes and nails. The composition of fixed costs on and variable costs of the fish business results in total cost, as can be presented in Table 2.

Table 2. Cost of fish business in Ranau Lake, 2016

\begin{tabular}{|c|c|}
\hline Cost & Amount (Rp/yr) \\
\hline 1. Fixed cost & 66.500 \\
Bamboo & 270.000 \\
Waring & 339.000 \\
Wooden beams & 33.800 \\
Ropes & 26.280 \\
Nails & 735.580 \\
\hline Amount of fixed cost & \\
\hline 2. Variable cost & 2.599 .000 \\
Seeds & 25.440 .000 \\
Feed & 45.960 \\
Medicine & 2.620 .000 \\
Labor & 30.704 .960 \\
\hline Amount of variable cost & 31.440 .540 \\
\hline Amount of fish business cost & \\
\hline
\end{tabular}

Production is the result obtained by fish farmers at harvest time. Each fish farmer expects that the fish business will benefit greatly, it is seen from how the farmers more improve the attention to the fish business. Prices of fish mujair at the time of the study average of Rp. $25.000 / \mathrm{kg}$ with an average production of $7196 \mathrm{~kg}$ a year. Acceptance obtained from the business is Rp. 179.900 .000 a year. The details of production, price, and acceptance of fish business at South OKU Regency can presented in Table 3 below:

Table 3. Revenue of fish business in Ranau Lake, 2016

\begin{tabular}{|c|c|c|}
\hline No & Item & Amount \\
\hline 1 & Production $(\mathrm{Kg} / \mathrm{yr})$ & 7.196 \\
2 & Price $(\mathrm{Rp} / \mathrm{Kg})$ & 25.000 \\
3 & Revenue $(\mathrm{Rp} / \mathrm{yr})$ & 179.900 .000 \\
\hline
\end{tabular}


Table 4 shows that the average production of the fish business at the time of study was $7196 \mathrm{~kg}$ a year or 7 tons a year, quite high as compared to the freshwater fish business in South Bengkulu Regency by [1] research is 5 ton a year. This indicates that the production of fish business around Lake Ranau is promising with the condition of Lake water is still very good for the development of fish business using floating net cages pattern. Furthermore, the amount of income received by fish business can be presented in Table 4 below:

Table 4. The income of fish business in Ranau Lake, 2016

\begin{tabular}{|c|c|c|}
\hline No & Item & Amount \\
\hline 1 & Revenue (Rp/yr) & 179.900 .000 \\
2 & Production cost (Rp/yr) & 31.440 .540 \\
3 & Income (Rp/yr) & 148.459 .460 \\
\hline
\end{tabular}

The income of fish business is obtained from the reduction of revenue with total cost based on the result of the analysis of the fish business acceptance of Rp.179.900.000 a year and the production cost of Rp. 31.440 .540 a year, then the income of Rp. 148.459.460 a year or Rp. 12.371.621 a month. Furthermore, the risk of fish business at Ranau Lake can be counted [5] and presented in Table 5 below :

Table 5. The risk of fish business income at Ranau Lake, 2016

\begin{tabular}{|c|c|c|}
\hline No & Item & Amount \\
\hline 1 & Average of income (Y) & 148.459 .460 \\
2 & Samples (n) & 62 \\
3 & Standar Deviation (V) & 13.242 .654 .95918 \\
4 & Coeficient of Variation (CV) & 0,0892004791 \\
5 & Income limitation (L) & 121.974 .15008164 \\
\hline
\end{tabular}

Table 5 shows that the fish business produces coefficient of variation less than $0.5(0.0892004791 \leq 0.5)$ and L over $(121.974 .150,08164 \geq 0)$. This means that the business is likely to avoid losses. Revenue owned by fish farmers in the research location is quite high that is Rp.148.459.460 a year or Rp.12.371.621 a month. High enough income will affect the behavior of fish farmers in facing risks, where they can carry out various strategies in dealing with problems that during the business. With considerable income, some risks that fish farmers can avoid include weather conditions, disease attacks, high feed costs, and human resources. Compared with [1] research, The Revenue and Risk Analysis of Freshwater Fish Cultivation in South Bengkulu Regency. The results showed that the income of freshwater fish cultivation, especially mujair fish is Rp. 59,512,743.75 of planting season, and fall into high risk category, the cause of the high risk of freshwater fish culture is the risk of disease attack and the high cost of feed and the lack of government attention to the quality of the cultivation, resulting in a decrease in quality.

\section{Conclussion}

1. The average income of fish business in Ranau Lake of South OKU Regency, South Sumatera Indonesia is Rp.148.459.460 a year.

2. The risk level of fish business in Ranau Lake of South OKU Regency, South Sumatera Indonesia is protected from loss.

\section{References}

1. Andani. Revenue Analysis and Business Risk of Freshwater Fish Cultivation (University of Bengkulu, 2014).

2. Davies J.G, Claridge, Nirarita. The Benefits of Wetlands : Potential of Wetlands in Supporting and Maintaining Development (Asean Development, 1995)

3. Departement of Fisheries and Marine of South Sumatera. Fishery Statistics of South Sumatera (Palembang, 2017)

4. Ginting. Journal of Coastal Resouces Management and Marine 1, 2 (1998)

5. Kadarsan. Risk and Uncertainties in Agribusiness, Theory and Application (Raja Grafindo Persada, Jakarta (1995)

6. Sutiana. Freshwater Fish Hatchery (Kanisius, Jogjakarta, 2012) 